Article

\title{
Agri-Food Chain Establishment as a Means to Increase Sustainability in Food Systems: Lessons from Sunflower in Brazil
}

\author{
Lucas Oliveira de Sousa $^{1,2,3, *}$, Marcelo Dias Paes Ferreira 4 (D) and Marcus Mergenthaler ${ }^{1}$ \\ 1 Faculty of Agriculture, South Westphalia University of Applied Sciences, Lübecker Ring \\ 2, 59494 Soest, Germany; mergenthaler.marcus@fh-swf.de \\ 2 Faculty of Agricultural Sciences, Hohenheim University, 70599 Stuttgart, Germany \\ 3 Departamento de Zootecnia e Extensão Rural, Faculdade de Agronomia e Zootecnia, \\ Universidade Federal de Mato Grosso, Av. Fernando Corrêa da Costa, 2367. Bairro Boa Esperança, \\ Cuiabá 78060-900, Mato Grosso, Brazil \\ 4 Escola de Agronomia, Universidade Federal de Goiás, Av. Esperança, s/n. Campus Samambaia, \\ Goiânia 74690-900, Goiás, Brazil; marcelo.ferreira@ufg.br \\ * Correspondence: lucas.o.sousa@gmail.com
}

Received: 11 May 2018; Accepted: 26 June 2018; Published: 28 June 2018

\begin{abstract}
The growing international food demand, the call for plant proteins to improve sustainability, the technological possibilities for sunflower protein ingredients, and the prominent role of Brazil in the world agricultural supply constitute the research background of this article. The aim is to analyze the process of establishment of the major sunflower agri-food chain in Brazil, seeking to support the future development of new sunflower chains to meet an expected increasing demand for high-quality sunflower proteins. A case study research design was applied, involving interviews with stakeholders from the input, farming, and processing segments. Moreover, the case analysis was guided by an analytical framework that regards the agri-food chain establishment as an entrepreneurial process. The findings show that the successful process of the sunflower agri-food chain establishment in Mato Grosso (MT) stems from a set of interconnected driving forces composed of entrepreneurial skills, social network, resource availability, and crop suitability. Furthermore, the analysis indicates the potential for the development of new sunflower chains among soybean farmers from other regions in MT, especially if new sunflower protein food ingredients lead to higher sunflowers prices, which would make this crop economically more attractive. Finally, this case study suggests that the collective establishment of agri-food chains is a challenging endeavor, especially if conducted by outside actors.
\end{abstract}

Keywords: agribusiness; collective action; double cropping; entrepreneurship; Mato Grosso; social networks; value chain

\section{Introduction}

The current scenario of the worldwide increase in food demand calls for substitution of animal protein for plant protein for human consumption to enhance the sustainability of food and agricultural production [1]. Overall, animal protein is regarded as a less sustainable protein source, since it is more natural-resource-intensive in comparison with plant protein [2], it is more costly for the food industry [3], and it is increasingly subjected to consumers' ethical concerns on animal welfare [4]. Consequently, the food research started to focus on the development of new sources and methods of plant protein production $[5,6]$. Soybean is currently the major source of plant protein food, with the widest range of applications [3,5]. Despite the lack of scientific consensus [7], there are increasing 
concerns about the use of genetically-modified soybeans, which have led many food manufacturers in Europe searching for alternative plant protein ingredients [8], among which sunflower appears as a promising raw material [5,8-10].

Against this background, the research project "Sustainable cultivation and novel processing of sunflower seeds for simultaneous production of sunflower oil, solid fuel and protein-rich food ingredients" (SunflowerProtein) has proposed a concept of sunflower processing that enables the recovery of vegetable oil, high-value food proteins, and solid fuels. This is achieved through a novel and sustainable technology for a complete utilization of all fractions of sunflower seeds, which allows the production of sunflower protein meals and concentrates suitable for human consumption instead of the low-value residues from conventional de-oiling, normally sold as livestock feed. Moreover, SunflowerProtein aims at ensuring and enhancing sustainability in agriculture, evaluating the cultivation of sunflower as an additional crop on existing agricultural areas in Brazil, seeking to enhance crop diversification, responsible land use, and farmers' income.

The sunflower sector is a small, but promising, agricultural sector in Brazil [11]. The sunflower production and processing is concentrated in three areas in the states of Mato Grosso (MT), Goiás/Minas Gerais (GO/MG), and Rio Grande do Sul (RS). Moreover, the planted area has never been greater than 150,000 ha, which represents less than $1 \%$ of soybean and maize planted areas [12]. Nevertheless, the country has potential for expanding the sunflower sector and can provide a supply side response to an expected growing demand for sunflower protein. The main reason for this is the suitability of sunflower to be grown after the harvest of soybean in the same growing season. The cultivated area of soybean in MT (9.3 million ha in 2016/2017) [12] indicates the enormous potential for an extension of the sunflower cultivation in soybean producing regions, as sunflower is cultivated in succession to soybean within a double-crop system. Furthermore, the introduction of sunflower in double cropping systems has been regarded in recent research articles as a way of improving the sustainability of the agricultural production system in Brazil, especially in MT, which leads the national production of soybean and sunflower. Several aspects support the association of sunflower with a more sustainable agricultural system in MT [11,13,14]. Sunflower farming takes place in existing grain-producing areas between February and July, when the weather conditions are less favorable to the infection with Sclerotinia sclerotiorum, a harmful pathogen common to sunflower and soybean (additional information on this issue is available in item 1 of the Supplementary Materials). Moreover, sunflower contributes to the pest management of certain nematodes infestation, which is a severe problem in grain-producing areas in Brazil. Furthermore, sunflower farming provides a viable additional income source for farmers, different from other non-commercial alternative cover crops available for farmers, such as millet, Crotalaria spectabilis, and $C$. ochroleuca. Finally, sunflower cultivation in succession to soybean reduces environmental impacts due to crop diversification, land use intensification, and the more efficient usage of production factors available on the farm, such as land, agricultural inputs, machinery infrastructure, and labor force.

Currently, only four agri-food chains produce and process sunflower into edible oil at the large scale in Brazil, among which a farmer-driven sunflower chain in MT stands out in terms of operational stability and efficiency, being the most recent, but the largest one, and the only one fully dedicated to the sunflower business [15]. However, the favorable agro-climatic conditions for sunflower cultivation at the farm level, combined with a demand increase related to high value-added food protein products, can drive the sunflower sector expansion in Brazil, leading to the establishment of new sunflower agri-food chains, especially in MT, which has led the Brazilian production of sunflower for more than a decade. Notwithstanding, these favorable conditions could not be sufficient to ensure well-developed sunflower chains in the country. Therefore, there is the need to understand the enabling factors for the establishment of sunflower chains in Brazil in order to set up successful strategies to meet the expected demand.

Therefore, this study aims at analyzing the establishment process of the leading sunflower agri-food chain in Brazil, based on the following research question: How can the underlying 
reasons for the sustainable farmer-driven sunflower agri-food chain initiative in Mato Grosso support the development of new sunflower chains in Brazil? Concentrating on this question, this study applies a case embedded design research approach involving stakeholders from the input, farming, and processing segments. Moreover, case analysis was guided by an analytical framework that regards the establishment of the sunflower agri-food chain in MT as an entrepreneurial process comprised of three stages-planning, implementation, and growth — with focus on the identification of the enabling factors for the process. The answer to this research question provides valuable information to the SunflowerProtein project regarding the role of MT as a future supplier of raw material for sunflower protein ingredients in the study region, besides indicating the potential for sunflower expansion to other areas.

Several subjects related to agri-food chains have been widely explored in the literature. Nevertheless, the effective establishment of agri-food chains is a critical and seemingly under-researched issue [16], suggesting the need for further understanding on the process of agri-food chain establishment. In other words, analyzing how an agri-food chain is formed, moving from the "non-established chain" to the "established chain" status. The existing research on this issue has mainly focused on the identification of hindering factors, challenges faced, and possible upgrading strategies related to agricultural chains established among smallholder farmers (e.g., the castor bean biodiesel chain in Minas Gerais, Brazil [17]; the palm biodiesel chain in the state of Pará, Brazil [18]; and the dairy goat agri-food chain in Tanzania [19]). Thus, this study contributes to shed more light on this issue, with a different approach, since we focused on the identification factors that have enabled a successful process of an agri-food chain establishment among large-scale farmers, which is relevant in the context of the agricultural production system in Brazil, in particular in MT.

The potential for sunflower expansion in grain-producing areas and the establishment of this crop in MT, Brazil's most important soybean producing region, have recently increased the interest in research related to sunflower in the country. Research topics include the analysis of the operation of national sunflower agri-food chains [15], the description of sunflower production in Brazil [11], a life-cycle assessment of the soybean-sunflower cropping system in MT [14], the analysis of sunflower genotypes' performance at different sowing dates in MT [20], the identification of nematode-resistant sunflower genotypes adapted to the tropical region of Brazil [13], the evaluation of agronomic characteristics of sunflower genotypes cultivated over different regions of the country [21-24], the analysis of technical characteristics of sunflower oils originated from several genotypes [25,26], and the investigation of the relationship between sunflower productivity and soil's chemical properties in MT [27]. Nevertheless, to date, no investigation has been conducted to understand the underlying reasons for the rapid development of sunflower sector in MT. Thus, this article provides an additional contribution for the sunflower research development in Brazil by addressing this issue, which can provide relevant information to public and private stakeholders aiming to foster sunflower production and processing to meet an expected increasing demand for high-quality sunflower protein.

\section{Analytical Framework}

This study regards the establishment of an agri-food chain as a process of collaboration among individuals and organizations to establish a new business based on a specific crop or livestock at different chain segments (input, farming, and processing) within a particular region and under a certain governance structure. Although this phenomenon could be analyzed under different theoretical approaches (e.g., supply chain management, and Marshall industrial district approach), the entrepreneurial approach seems particularly suitable for analyzing the establishment of the sunflower agri-food chain, once the research field of entrepreneurship is fundamentally concerned with understanding how economic activities come into existence [28]. Moreover, the definition of entrepreneurship as a process that includes the discovery, enactment, evaluation, and exploitation of opportunities to create future goods and services [29] also points to the suitability of entrepreneurship to support the analysis of the sunflower chain establishment performed in this study. Thus, inspired by 
the model of the entrepreneurial process [30], we propose a framework to analyze the sunflower agri-food chain establishment as a process comprising three stages-planning, implementation, and growth, which are influenced by enabling factors (Figure 1).

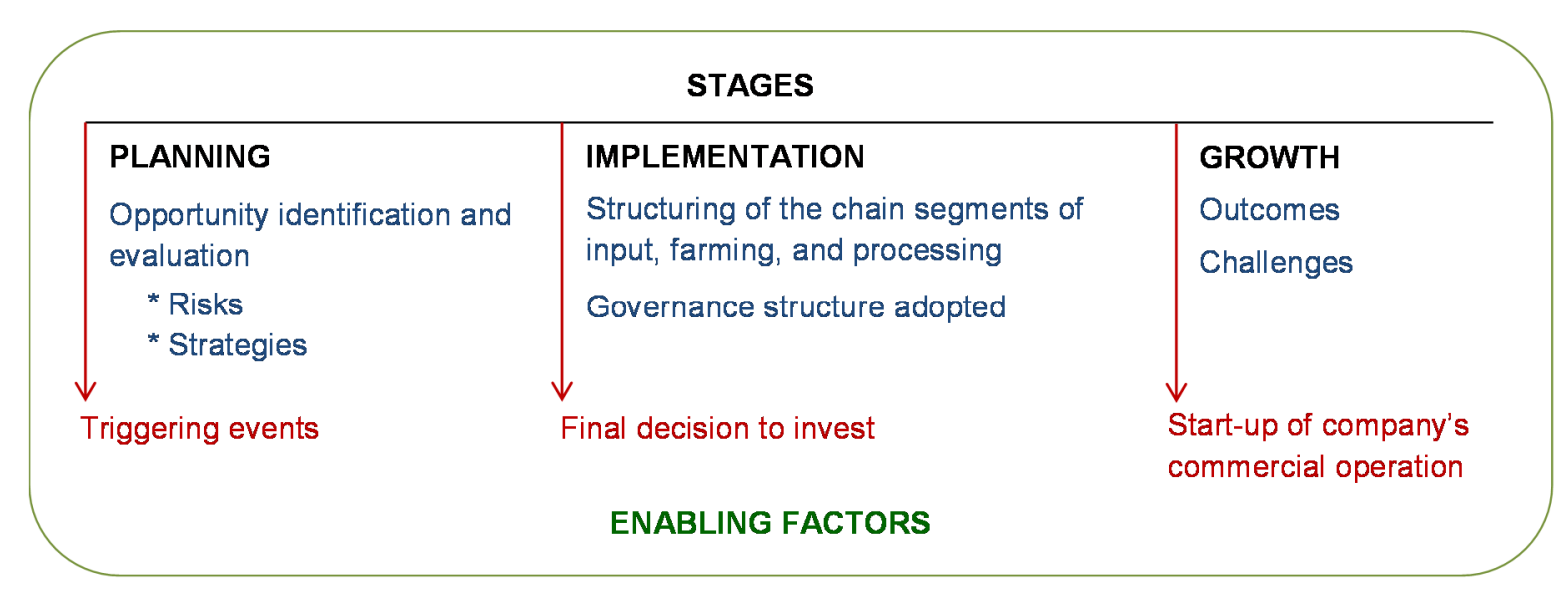

Figure 1. Analytical framework of the process of sunflower agri-food chain establishment.

The planning stage begins with triggering events that lead to the initiation of the agri-food chain establishment process. In this stage, the focus is put on analyzing how the opportunity related to sunflower was identified and evaluated, which includes the identification of risks and risk-minimizing strategies, if any, applied by the organizing group. The identification and evaluation of business opportunities are a key part of entrepreneurship [31]. The implementation stage starts after the final decision to invest in the agri-food chain establishment. At this stage, the focus is set on identifying how the chain segments were structured and which governance forms were adopted to coordinate the economic activities of the nascent chain. In the context of agri-food chains, contractual and relational governance structures can be used to rule the economic transactions [32,33]. The start-up of company's commercial operation, in turn, marks the beginning of the growth stage. In this stage, the focus is set on analyzing the main outcomes and challenges over the agri-food chain growth trajectory.

Given that this study aims at understanding the underlying reasons for the success of a farmer-driven agri-food chain initiative, this implies necessarily the identification of factors that enabled the accomplishment of each process stage. Enabling factors are related to the individuals involved in the process and to the local and macro environment in which the endeavor takes place, including personal, sociological, environmental, financial, economic, legal, political, technological, and organizational factors $[30,34]$. Concerning the personal factors, the entrepreneurial skills of the actors involved in the chain establishment process are an important part of the enabling factors. Entrepreneurial skills include: initiative, an opportunity-seeking behavior, the ability to detect, develop, and implement opportunities, a planning capacity, a forward-looking vision, creativity, the willingness for taking calculated risks, the focus on the achievement of goals, perseverance, determination, and ability to react to frustration, a network of contacts, leadership, a wealth and value-seeking behavior, business field experience, market orientation, and management ability [35]. Thus, the present framework seeks to guide the analytical description of the sunflower agri-food chain establishment process, focusing on the identification and analysis of its enabling factors.

\section{Methodology}

This paper applies a case study approach, which is a suitable research method for investigating underlying processes that might explain complex social-economic phenomena out of researchers' control in its real-world context [36], such as the establishment process of a sunflower agri-food chain. For this reason, the case study is a useful methodological tool for the agribusiness research [37], being largely adopted by researchers of this field. 
More specifically, we adopted a case embedded design (Figure 2), in which different embedded units of analysis are considered within an unit of analysis that is, in turn, surrounded by a contextual environment [36]. The unit of analysis is the main sunflower agri-food chain in Brazil, located in the state of Mato Grosso (MT). The embedded units of analysis refer to the chain segments of inputs, farming, and processing.

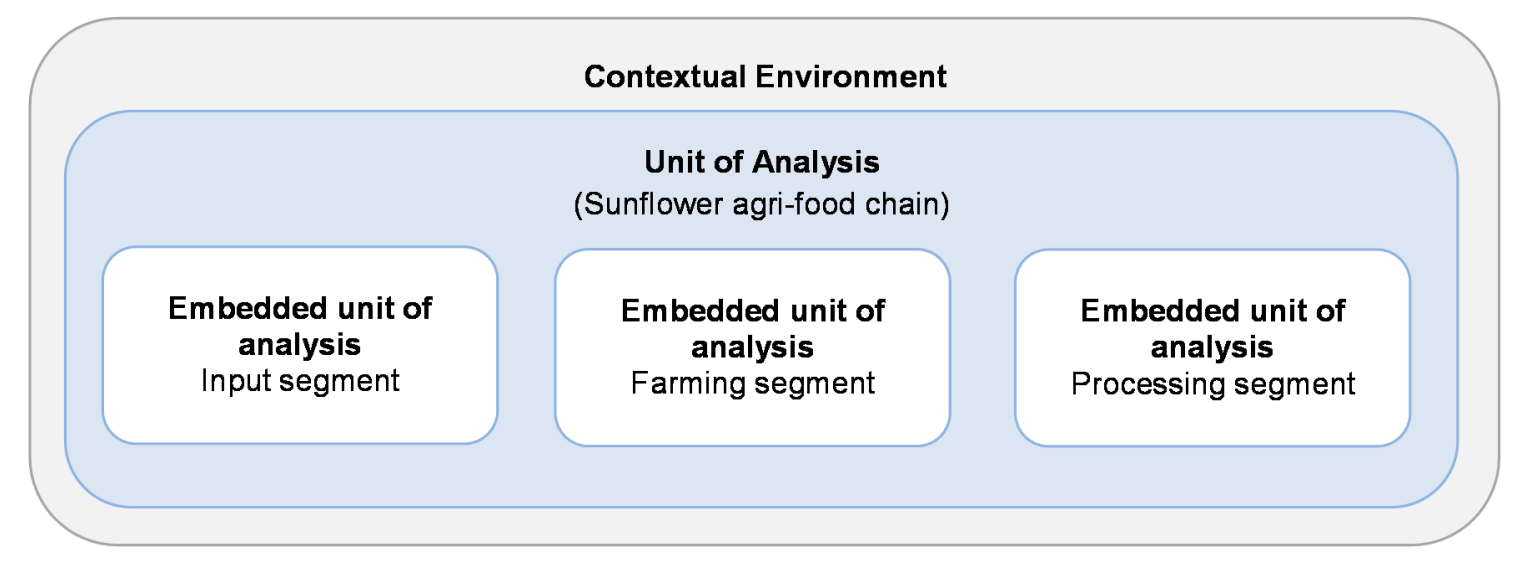

Figure 2. Case embedded design adopted in this study.

The first author carried out a fieldwork for gathering information in the sunflower-producing area in MT. The fieldwork was carried out in five municipalities-Campo Novo do Parecis, Brasnorte, Sapezal, Campos de Júlio, and Sorriso. The main area, however, was Campo Novo do Parecis, where the processing company is located and where most of the individuals involved in the agri-food chain establishment reside.

The identification of research participants/respondents started in 2014 and 2015. In this period, two meetings were held in Campo Novo do Parecis to present the research project SunflowerProtein to stakeholders of the existing sunflower agri-food chain, which is the unit of analysis of the present article. During the fieldwork between April and July 2016, the first author selected the interviewees from the different embedded units of the analysis. The criterion used for selecting the informants was the participation in the process of sunflower chain establishment. In this regard, the starting point was the contact with the processing company representatives, who indicated farmers and agents from the input segment that were part of the sunflower chain initiative. Additionally, the time spent by the first author living in the study region and the informal relationships established with local agricultural agents also contributed to the identification of 27 sunflower agri-food chain stakeholders from the input, farming, and processing segments, besides representatives from the research sector willing to participate in the study (Table 1). The apparent high number of interviews with input suppliers in comparison with interviewees from the farming and processing segments is due to higher diversity verified in that segment especially in terms of seed brands. Typically, each input provider is a dealer of only one of the five sunflower seed companies with commercial representation in the region. Therefore, we sought to capture the perspective of input actors related to different seed companies. Moreover, although researchers are not part of an embedded unit of analysis, their inclusion contributes to the comprehension of the contextual environment in which the sunflower chain endeavor takes place. Among the farmers, two interviewees stood out due to their leadership position in the chain establishment process. 
Table 1. Description of the recorded interviews.

\begin{tabular}{ccc}
\hline Interviewed Group & Number of Interviewees & Average Length of the Interviews (min) \\
\hline Processing & 1 & 100 \\
Farming-leaders & 2 & 65 \\
Farming-others & 12 & 12 \\
Input suppliers & 8 & 38 \\
Local research & 2 & 26 \\
National research & 2 & 20 \\
\hline
\end{tabular}

The interviewees were initially contacted by telephone to check their availability and then visited by the first author mostly at their workplace. Information gathering were based on open-ended questions interviews adapted to each group of interviewees, aiming at understanding how the sunflower agri-food chain establishment process has been organized and which factors have enabled the involvement of actors from different chain segments in this endeavor. The interviews were audio-recorded with interviewees' permission and amounted to around 770 minutes (average lengths are shown in Table 1). Interviews were transcribed and amounted to around 130 pages. The case study analysis sought to identify in the interviews the underlying causes for the successful sunflower agri-food chain establishment in MT. In this regard, the qualitative data analysis software MAXQDA (version 11, VERBI Software GmbH, Berlin, Germany) assisted the process of interview transcripts analysis, enabling the development of a coding system to simultaneously tag multiple interview quotes.

\section{Results}

\subsection{Description of the Sunflower Agri-Food Chain Establishment Process}

\subsubsection{Planning Stage}

The planning stage of the sunflower agri-food chain in Mato Grosso took place in Campo Novo do Parecis in 2006. A set of factors triggered this collective farmer-initiative, including difficulties related to their unfavorable geographical location, high transportation costs, and low maize prices at that time, a collective desire for adding value to their agricultural production and for boosting the local economy, as well as role models from successful agro-industrialization experiences in other regions of MT, such as in Lucas do Rio Verde.

The sunflower chain opportunity identification and evaluation had a collective and self-organized approach. Local farmers led group discussions about different agro-industrialization investment possibilities for their locality and contracted out a feasibility study to support their decision-making process. Moreover, the reputation, experience, and leadership of a group member (hereafter called reference farmer (for additional information about the reference farmer, please see item 2 of the Supplementary Materials) influenced the collective decision to focus the chain on a non-established crop, as was the case of sunflower in MT. In this regard, the group composition was a key issue for the whole chain establishment process. Mutual trust, and good professional and personal reputation were the main criteria for the members' selection. Furthermore, previous joint experiences and common goals influenced the group organization. The members were mostly farmers (about 40) from the micro-region of Parecis, in MT, owners of large-scale mechanized farms focused on the production of soybean, maize, and cotton. In addition, the group members had management experiences from other agricultural businesses, besides being involved in other innovative actions, like the introduction of maize popcorn cultivation in the state. Additionally, the leadership skills of some group members and the technical and commercial sunflower expertise of the reference farmer contributed to encourage members without experience with sunflower to join the endeavor. Table 2 highlights the main enabling factors underlying the planning stage of the sunflower agri-food chain. These factors are related to the 
organizing group, to the crop suitability, and to the market opportunity, which jointly led the group to decide for the establishment of the sunflower agri-food chain.

Nevertheless, there were risks of failure at the farming and processing levels related to the insipient development stage of the sunflower sector in Brazil at that time and related to the overall lack of experience of the group members on sunflower cropping and processing. Aware of this, the group defined a set of risk mitigation strategies to be applied in the next chain establishment stages (Table 3).

Table 2. Enabling factors for the planning stage.

\begin{tabular}{cl}
\hline \multicolumn{1}{c}{ Category } & Enabling Factors \\
\hline \multirow{2}{*}{ Organizing group } & $\begin{array}{l}\text { (1) Mutual trust. (2) Previous joint experiences. (3) Participation of individuals related } \\
\text { to the input segment of other crops (owners of farm supply retail stores and seed } \\
\text { companies representatives). (4) Large-scale farm infrastructure. (5) Availability of own } \\
\text { financial resources. (6) One reliable farmer with expertise on sunflower (reference } \\
\text { farmer). (7) Leadership skills of some members. (8) Members' expertise in crop } \\
\text { production. (9) Management experience. }\end{array}$ \\
\hline Crop suitability & $\begin{array}{l}\text { (1) Favorable soil and weather conditions for the cultivation of sunflower. } \\
\text { (2) Additional crop with low need of specific investment (additional income and } \\
\text { dilution of fixed costs). (3) Suitability of sunflower for the local farm production system. } \\
\text { (4) Agronomic benefits (soil quality improvement related to crop rotation). }\end{array}$ \\
\hline \multirow{2}{*}{ Market opportunity } & $\begin{array}{l}\text { (1) Market opportunity for sunflower oil-very few companies processed sunflower } \\
\text { into oil in Brazil. }\end{array}$ \\
\hline
\end{tabular}

Table 3. Risks identified and risk-minimizing strategies defined by the group.

\begin{tabular}{|c|c|}
\hline Risk Sources & Risk Mitigation Strategies \\
\hline $\begin{array}{l}\text { (1) Low level of knowledge on sunflower production. } \\
\text { (2) Inexperience in the vegetal oil processing segment. } \\
\text { (3) Absence of an organized sunflower input segment } \\
\text { in Brazil. (4) Low technological level in terms of seeds } \\
\text { and agrochemicals in comparison with } \\
\text { well-established crops (soybean and maize). (5) Very } \\
\text { limited market structure on both the supply and } \\
\text { demand side. }\end{array}$ & $\begin{array}{l}\text { (1) Gradual development of the processing facility. } \\
\text { (2) Investing in a multiple oilseeds processing plant } \\
\text { able to process soybean (farmers' main crop) in case } \\
\text { of shortage of sunflower. (3) Setting up the company } \\
\text { as joint-stock company. (4) Organizing the diffusion } \\
\text { of sunflower production knowledge. }\end{array}$ \\
\hline
\end{tabular}

\subsubsection{Implementation Stage}

The strategies defined in the planning stage were put in place during the implantation stage that began in 2006. Table 4 displays the structuring activities and the enabling factors for this stage. The organizing group was responsible for structuring the sunflower farming and processing segments. This included self-organizing activities to disseminate knowledge on sunflower cultivation among the group members. In this regard, the fact that sunflower was a non-established crop plant in Brazil coupled with the leadership, personal, and professional reputation of the reference farmer, placed this farmer as the focal point for the knowledge diffusion due to his greater experience in sunflower farming. Nevertheless, the knowledge diffusion had a collective approach supported by a favorable institutional environment of mutual trust, synergies, and previous joint experiences, as well as the agricultural expertise of all members of the group. Moreover, farmers led the construction of the processing facility on a shared self-financed basis, as well as the hiring and training of local labor force. In this regard, the small initial processing capacity, the incipient sunflower sector in Brazil, and the unfavorable geographical location of Campo Novo do Parecis limited company's capacity to hire skilled labor with experience in the business of sunflower. Therefore, at this stage, the building of competencies on industrial processing was a learning-by-doing process that involved the training of local labor force formerly from other agro-industrial sectors and a partnership with the company responsible for the development of the mechanical screw press for sunflower oil extraction. 
The role of seed companies' representatives started at this stage with the initial establishment of sunflower seed companies' dealers in the region. This fact was a relevant step in the chain establishment process. Since sunflowers could be grown using the existing farm resources available for maize and soybean, the primary input needed for the chain establishment was the sunflower seed, which at that time was not readily available in that region. The actors were attracted by the expectation of profitable participation in the nascent agri-food chain due to the ownership of the processing company by farmers with individual large-scale farm production infrastructures and reliable social and professional reputation. Additionally, the fact that some group members operated in the input segment of other crops facilitated the entry of sunflower seed companies' dealers into the region.

The implementation stage lasted until 2008. The main reason for its relatively large duration was an operational problem that required a new investment and delayed the conclusion of the processing plant. During this situation, another company that operated in the sunflower seed and processing segments in southern Brazil supported the farmers' initiative by buying the entire sunflower production while their processing facility was not finished.

Table 4. Implementation of the sunflower agri-food chain segments.

\begin{tabular}{cll}
\hline Chain Segment & Structuring Activities & Enabling Factors \\
\hline Farming & $\begin{array}{l}\text { (1) Diffusion of sunflower production } \\
\text { knowledge. (2) Provision of feedstock } \\
\text { for the processing company. }\end{array}$ & $\begin{array}{l}\text { (1) Expertise and reputation of the reference farmer. (2) Teamwork } \\
\text { culture. (3) Mutual trust and commitment of the group members. } \\
\text { (4) Low need of specific investment (synergies). }\end{array}$ \\
\hline \multirow{2}{*}{ Processing } & $\begin{array}{l}\text { (1) Construction of the processing } \\
\text { facility (20 tons/day). (2) Hiring and } \\
\text { training of local labor force. }\end{array}$ & $\begin{array}{l}\text { (1) Availability of financial resource. (2) The commitment of the } \\
\text { group members. (3) Managerial skills. (4) Support from another } \\
\text { sunflower processing company. }\end{array}$ \\
\hline Input & $\begin{array}{l}\text { Initial establishment of sunflower seed } \\
\text { companies' dealers in the region. }\end{array}$ & $\begin{array}{l}\text { (1) Group members' reputation. (2) Farms' large-scale production } \\
\text { capacity. (3) Group members from the input sector of other crops. } \\
\text { (4) Synergies with other crop business units. }\end{array}$ \\
\hline
\end{tabular}

Regarding the governance mechanisms, relational governance and informal contracts were the means adopted for coordinating the economic activities between farmers and the processing company (Table 5). Contracts specifying a set of items organized the provision of sunflower among members. However, the contracts were, in general, simple communication forms (e.g., an e-mail) instead of formal written contracts. This governance arrangement was possible due to the trusting relationships within the group as well as the members' engagement and commitment to the agri-food chain establishment, which minimized transaction costs related to agents opportunism, lessening the risk of transaction failure. In that sense, social control and self-enforcing mechanisms for transactions among group members made trust the main transactions governance form at that stage.

Table 5. Transaction coordination mechanisms.

\begin{tabular}{ll}
\hline Governance Forms & Contract Items \\
\hline & $\begin{array}{l}\text { (1) Sunflower planted area (ha). (2) Price defined before the beginning of } \\
\text { the season that sought to guarantee sufficient profitability for farmers } \\
\text { (1) Relational governance (trust). } \\
\text { (2) Informal contracts }\end{array}$ \\
& \begin{tabular}{l} 
delivery. (4) Feedstock delivery done by farmers. \\
\hline
\end{tabular}
\end{tabular}

\subsubsection{Growth Stage}

The growth stage started in 2008 with the beginning of the company's commercial operation in the sunflower edible oil market for industrial consumers. Table 6 lists the outcomes and the enabling factors for this stage. The three chain segments have consolidated in the region, which became the major center of sunflower production and processing in the country. The interdependency of the chain segments is highlighted at this stage since the consolidation of each segment enabled the consolidation of others segments in a kind of "feedback loop" necessary for the development of the agri-food chain. 
Furthermore, the strategies defined in the planning stage proved to be effective in the growth stage. Given that the operational and administrative processing company's personnel had no previous experience in the business of sunflowers, the strategy of gradual development enabled the progressive obtainment of sunflower processing and market expertise. Moreover, the knowledge diffusion activities achieved the goal of spreading sunflower production knowledge among farmers; and the setting up of the company as a joint-stock company shared the risks and facilitated the entry of an industrial shareholder that resulted in the last and most significant expansion and modernization of the processing company in 2014. The industrial shareholder acquired 30\% of the company's capital and supported the investment in a modern oilseeds solvent extraction plant capable of processing up to 600 tons of sunflower per day. Moreover, this new shareholder brought technical expertise in the process of oilseeds solvent extraction to the group, which, until then, operated exclusively with a mechanical screw press. The group of farmers, in turn, maintained the majority control of the company and accounted for most of the investment. In this sense, a program of public incentive for industrialization was also decisive for the expansion of the company, since it provided the members of the group with financial credit and fiscal conditions on advantageous terms.

With the successive expansions of processing capacity, non-shareholders farmers started to supply sunflower to the company. Despite the successful establishment of sunflower cultivation in the region, this crop has faced some technological limitations (e.g., concerning seed adaptability and agrochemicals availability), especially in comparison with well-established and competing crops, as maize. This fact have limited the interest of some group members (owners of large farms) to allocate large shares of their land to sunflower (as a risk-minimizing strategy). Therefore, the entry of external or non-shareholder suppliers sought to meet the demand increase generated by the growth of the processing company. In this respect, the participation of stakeholders from the input segment has played an important role for the attraction of new sunflower suppliers. Those actors link new sunflower suppliers to the processing company, being responsible for providing farmers with inputs (especially seeds), technical assistance, and contract within an environment highly influenced by social networks and trust. The active participation of input segment actors in the sunflower agri-food chain operation is another indication of its effective establishment and provides a win-win situation. While these agents benefit from the sale of inputs, non-shareholder farmers benefit from the technical assistance received and the connection with the processing company, and shareholders-farmers benefit from the sunflower business consolidation. Moreover, farmers' majority participation in the ownership of the processing company gives them the role of coordinating the sunflower agri-food chain, being responsible for relevant operational and strategic decisions (e.g., the decision to expand and modernize the processing company). With the entry of the industrial shareholder and the non-shareholders sunflower suppliers, formal contracts replaced the informal ones, although relational governance has remained as a complementary governance structure.

The consolidation of the sunflower agri-food chain in MT is also related to the market in which the company decided to operate. Farmers' decision to target the market of non-refined sunflower oil for food industry consumers appears to have been the most viable one considering the limited sunflower oil market structure and the gradual development approach adopted by them. By targeting this market, the company avoided competing with large and well-established food companies that dominate the market of sunflower refined oil for final domestic consumers. Furthermore, the high investment necessary to enter in the sunflower processing sector competing with big players would make the gradual development approach not suitable, precluding the establishment of farmer's company. Moreover, the buyer power of its clients is lessened, due to the insufficient national supply of sunflower oil, and the comparative advantage of farmers' company regarding its ability to supply small volumes of sunflower oil to its customers, which alternatively would have to import larger amounts of the product mainly from Argentina. Additionally, as the food industry has rigorous feedstock quality standards, the recognition of the quality of the oil regarding fatty acids components and oil purity by the buyers since the beginning of company's commercial activities was essential for 
company's consolidation in the market. Finally, the development of a regional market of sunflower seed cake/meal (sunflower oil byproduct) for livestock feed also contributed to the chain establishment due to the generation of additional revenue.

Table 6. Outcomes of the growth stage and their enabling factors.

\begin{tabular}{|c|c|}
\hline Outcomes & Enabling Factors \\
\hline $\begin{array}{l}\text { (1) Consolidation of the company in the domestic } \\
\text { market of sunflower unrefined oil for food } \\
\text { industry consumers. }\end{array}$ & $\begin{array}{l}\text { (1) Product quality recognized by the buyers. (2) Lower competition than in the } \\
\text { market of refined sunflower oil for final domestic consumers. (3) Company's } \\
\text { ability to provide small loads to its clients. }\end{array}$ \\
\hline $\begin{array}{l}\text { (1) Development of a regional market for sunflower } \\
\text { seed cake/meal for livestock feed. }\end{array}$ & $\begin{array}{l}\text { (1) Regional demand. (2) Attractive price in relation to soybean meal. (3) Farmers } \\
\text { social networks and managerial skills. }\end{array}$ \\
\hline $\begin{array}{l}\text { (1) Consolidation of the region as main national } \\
\text { sunflower producing area. (2) Expansion of the } \\
\text { sunflower production knowledge. }\end{array}$ & $\begin{array}{l}\text { (1) Cohesion, commitment and consistency of the group. } \\
\text { (2) Large agricultural area available in the region. (3) Large-scale and mechanized } \\
\text { farm infrastructure. (4) Consolidation of the input and processing segments. } \\
\text { (5) Knowledge diffusion activities organized by farmers, processing company } \\
\text { and seed providers. }\end{array}$ \\
\hline $\begin{array}{l}\text { (1) Consolidation of a local sunflower input segment } \\
\text { (five seed companies set up local dealers in the } \\
\text { region). }\end{array}$ & (1) Consolidation of the processing and farming segments. \\
\hline $\begin{array}{l}\text { (1) Entry of non-shareholders sunflower suppliers } \\
\text { (replacement of informal contracts by formal ones). }\end{array}$ & $\begin{array}{l}\text { (1) Support provided by stakeholders from the input segment-provision of } \\
\text { technical assistance and linking farmers to the processing company via contract. } \\
\text { (2) The role model from farmers of the organizing group, (3) Synergies (additional } \\
\text { crop with low need of specific investment } \rightarrow \text { additional income and dilution of } \\
\text { fixed costs). } \\
\text { (4) Consolidation of the agri-food chain. }\end{array}$ \\
\hline
\end{tabular}

Despite its successful development, the sunflower agri-food chain in MT has faced challenges over the growth stage period. The main one refers to the instability in the sunflower production area over the years. This instability is related to the fact that the sunflower remains as a non-established crop, therefore, being highly subjected to land use competition with maize. The latter crop is also grown in the second season after the harvest of soybean; however, maize is a well-established crop with better market liquidity and technological conditions in comparison with sunflower. Thus, as farmers are usually more willing to grow maize, especially in years of soaring prices, sunflower becomes comparatively less profitable than maize. Consequently, the company faces difficulties in generating sufficient value (regarding sunflower price) for its feedstock suppliers, especially for non-shareholders farmers. Moreover, high energy costs and the long distance of the processing company to the main consumer markets (over $1500 \mathrm{~km}$ ) associated with poor road conditions have affected the company's competitiveness. Additionally, the sunflower oil demand side limitations combined with macroeconomic conditions have also impacted the sunflower chain development in the last four years. Once sunflower oil is part of a niche market within the edible vegetable oil sector in Brazil, the country's economic performance affects directly the demand for this product, which is two to three times more expensive than soybean oil (main vegetable oil consumed in Brazil). Furthermore, given the insufficient domestic production of sunflower oil in Brazil, in periods when the Brazilian currency (Real) appreciates against the US dollar, sunflower oil importation costs decrease, favoring imports from Argentina-the main producer in South America. 


\section{Discussion}

The process of the sunflower agri-food chain establishment in Mato Grosso has proven to be a sustainable/lasting and complex social-economic endeavor stemming from a set of interconnected driving forces composed of entrepreneurial skills, social network, resource availability, and crop suitability. These components favored horizontal cooperation and downstream collective vertical coordination, allowing farmers to independently identify and develop the opportunity related to the sunflower agri-food chain, overcoming barriers associated to the initial development stage of the sunflower sector in Brazil, besides reducing risks of transaction failure and favoring company's consolidation in the market.

Triggering events provided the initial stimulus for downstream collective vertical integration, which, combined with the driving forces, favored the establishment of a sunflower agri-food chain in the micro-region of Parecis, MT. Figure 3 summarizes the triggering events as well as the driving forces, their sources, and their outcomes for this sustainable collective entrepreneurial agri-food chain endeavor. The set of driving forces enabled a short, but efficient, planning stage, facilitated the chain segments structuring and a knowledge diffusion scheme in the implementation stage, besides having ensured the chain continuity and expansion in the growth stage.

The entrepreneurial skills component led the group confronting limitations (e.g., unfavorable geographical location), adopting a strategic decision-making approach (e.g., definition of chain focus and risk-mitigating strategies), and supporting the agri-food chain planning, implementation, and growth. In this regard, the main entrepreneurial skills emerged from the process were leadership, initiative, the ability to detect and develop opportunities, planning capacity, a forward-looking vision, the willingness to take calculated risks, the perseverance, determination and ability to react to frustration, a network of contacts, business field experience and market orientation, as well as management skills. Conversely, the lack of stakeholders' entrepreneurial orientation hinders the development of agri-food chains, such as that observed in organic citrus chains in Greece [38]. Furthermore, the sunflower case study points to the benefits of collective entrepreneurship [39], since the high entrepreneurial skills of some members had a positive spillover effect on other members with less entrepreneurial skills. This has been made possible by the social network component.

The sunflower case study confirms the idea that social relations embed and shape economic actions [40,41]. In this regard, the composition of the organizing group based on mutual trust and common goals was a key factor that assured members' commitment and cohesion over time. It was fundamental for the agri-food chain implementation and operation. The importance of members' selection was also observed in collective agricultural businesses in Sri Lanka [42], where the selection of entrepreneurial farmers to run agricultural enterprises was indicated as a key factor for a company's sustainable operation. This is highlighted in the sunflower case by the paramount influence that a few members had on the chain establishment process due to high levels of leadership capacity, managerial skills, and technical expertise in such a way that, without them, the chain endeavor might not have occurred. Furthermore, the group members' formation highlighted the role of previous successful experiences (long-term relationships), and social and economic reputation as trust-builders [32,43-45]. Moreover, members' good reputations contributed to attract other stakeholders to the sunflower agri-food chain in the implementation and growth stages. Additionally, farmers' trustful relationships reduced transaction costs, encouraging them to jointly invest in specific assets $[43,46]$, besides having favored horizontal cooperation (e.g., in terms of knowledge diffusion process) and vertical coordination, since the group trusted the members in charge of leading the company $[43,44,47]$. The present case study also evidenced that trust can be the main primary governance structure [41] in early chain development stages while the economic activities are restricted to group members. Nevertheless, the agri-food chain expansion required the adoption of formal contracts to lessen the risk of transaction failure. 
Triggering events: unfavorable geographical location, high transportation costs, low maize prices, collective desire for adding value, and agro-industrialization role model

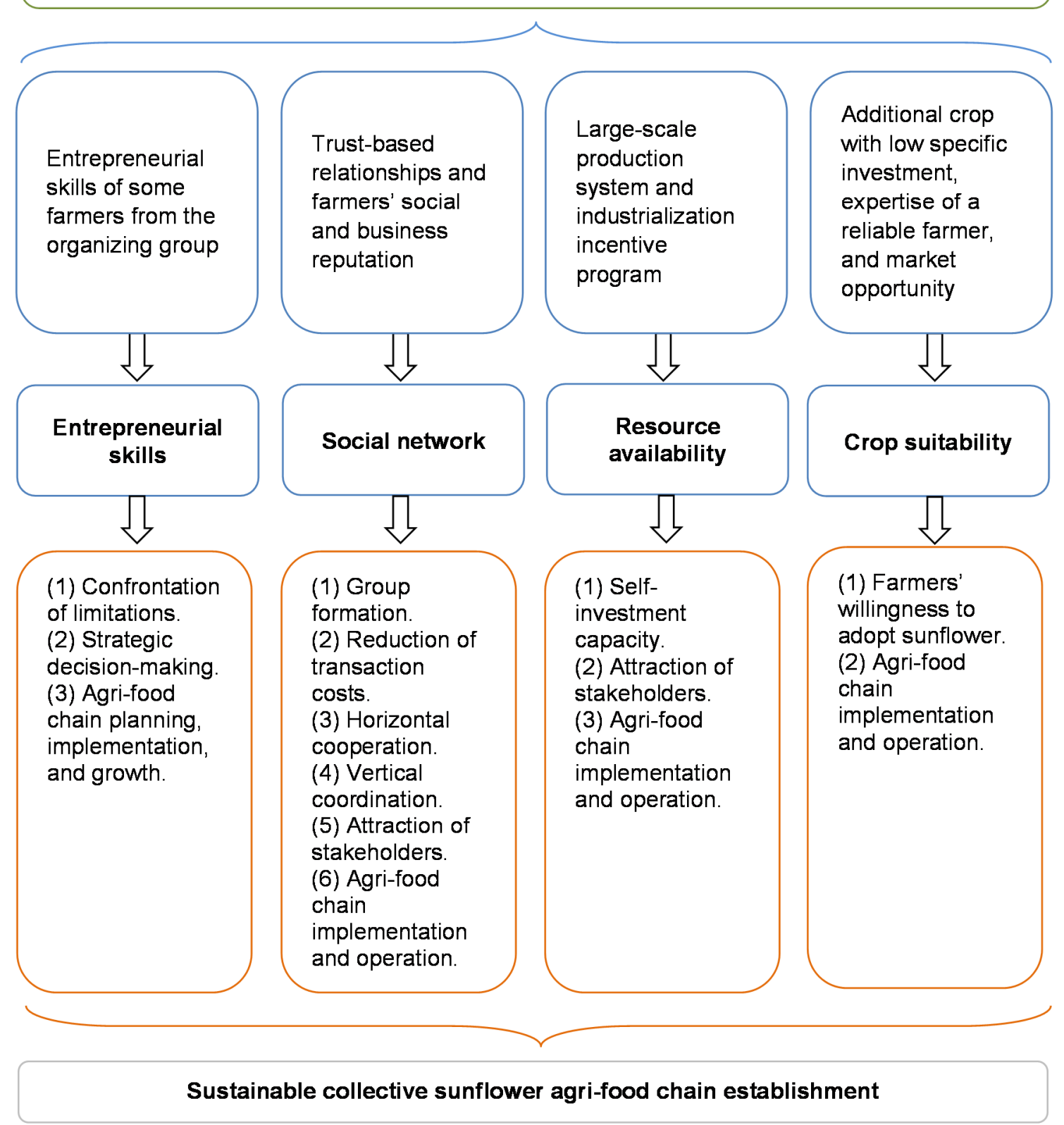

Figure 3. Reasons for the sustainable collective sunflower agri-food entrepreneurial endeavor in Mato Grosso.

The importance of resource availability for agricultural chains development [32] was highlighted in the sunflower case study due to its internal driven approach without support from intermediary organizations. In this regard, the fact that group members being large-scale farmers with other income sources than sunflower allowed them to bear implementation and operational costs and risks, especially in periods of company's financial difficulties. Furthermore, group members' large-scale production structure contributed to attract other stakeholders, since it offered certain investment security to sunflower seed companies' dealers that settled in the region and to the industrial shareholder that joined farmers' initiative. Moreover, the present case shows the importance that public incentive 
programs for industrialization have on supporting business expansion, by the provision of credit with low interest rates.

The suitability of sunflower both at the farming and processing levels was another underlying reason for the successful chain establishment. Although sunflower is a non-established crop in Brazil, the following aspects guaranteed at least a minimum level of farmers' willingness to adopt sunflower over time: (1) its dovetail with the local farm production system, not affecting farmers' main income source (soybean); (2) its low level of specific investments, sharing the productive resources available for soybean and maize; (3) the previous cropping experience of a reliable farmer with remarkable leadership capacity; and (4) the knowledge diffusion schemes. At the processing level, the suitability of sunflower could be seen by the operation in a market segment with low domestic competition that facilitated the company's consolidation in the market. Thus, crop suitability proved to be an essential factor for chain implementation and operation over time.

The crucial components for successful business endeavors are a good opportunity, good entrepreneurs, and availability of resources needed to initiate and to sustain the business growth [30]. These three components could be seen in the sunflower agri-food chain endeavor in MT, having been enabled by the driving forces that led its establishment process. In contrast, this has not been the case of other agricultural chain endeavors, especially among smallholder farmers. For instance, the castor bean biodiesel chain in Minas Gerais, Brazil is an example of how the lack of entrepreneurial approach (by the decision-makers from intermediary organizations and the farmers), weak social networks (lack of horizontal organization), resource scarcity, and crop inadequacy at the farming level can hinder an agricultural chain development even with favorable demand-side conditions (purchase and price guarantees) [17].

The findings from the sunflower case study suggest that the collective establishment of agri-food chains is a complex endeavor, especially if led by outside actors (e.g., intermediary organizations). The main reason for this complexity is that the driving forces underlying the successful agri-food chain establishment process are factors difficult to be framed or fostered. The development of entrepreneurial skills, in other words the idea of "making" entrepreneurs, is a topic that has not achieved a consensus in the literature on entrepreneurship. Nevertheless, it seems to prevail the idea that "making" entrepreneurs is possible and depends, on the one hand, on a certain predisposition to entrepreneurship, in terms of personality traits, and, on the other hand, on the access to proper tools to execute entrepreneurial endeavors, which can be obtained by training and from an enabling environment [48]. Although possible, this is undoubtedly a complex task, since there are multiple skills related to an entrepreneur, including technical, managerial, strategic, and market abilities [49]. Regarding social networks, evidence suggests that cooperation or willingness to cooperate is, in part, a cultural element [50]. Consequently, building up a propitious trustful environment for mutual horizontal and vertical collaboration among potential partners, essential for collective agri-food chain endeavors, is a time-consuming task [51]. Finally, although financial constraints are a strong barrier for any business development, including agricultural ones [32,42], the sunflower case study findings indicate that the provision of a physical structure appears as the most straightforward task for the agri-food chain establishment process, in comparison with the complexity of developing entrepreneurial competency and building trustful social networks among potential agri-food chain actors.

\section{Final Remarks}

Our findings suggest that the entrepreneurial skills of large-scale farmers within a social network based on trust and personal and professional reputation, coupled with crop suitability, are the main underlying reasons for the successful sunflower agri-food chain endeavor in the micro-region of Parecis, Mato Grosso, Brazil. The analysis of this farmer-driven agri-food chain suggests that the development of new sunflower agri-food chains to meet the expected demand increase for high added-value food protein could take place among soybean farmers from other agricultural regions in MT, especially if 
the new products lead to higher sunflower prices, which would make this crop more economically attractive than maize and cotton. In addition to the availability of arable land and resources suitable for introducing sunflower as a second-season crop, soybean farmers in MT share a similar cultural background of pioneering and collective actions [50] that lessens transaction costs and individual financial requirement, favoring horizontal cooperation and collective investment. These features evidence the existence of a supportive institutional environment for the collective establishment of new sunflower agri-food chains in MT. In this regard, the sunflower chain in Parecis serves as an important role model for soybean farmers from other agricultural regions in MT interested in engaging themselves in a collective sunflower agri-food chain endeavor. Among the several enabling factors identified across the different establishment process stages, the following ones seems to be fundamental for all others and, therefore, should receive special consideration: formation of a cohesive and committed organizing group comprised of trusted individuals, preferably with previous collaborative experiences and managerial skills; and the presence of at least one individual with distinguished leadership, technical, and market expertise related to the crop or livestock focus of the agri-food chain.

Further research is needed to investigate and estimate the potential for the expansion of sunflower diffusion to different agricultural regions of MT, taking into consideration land use competition issues with other crops available for the second crop season. Finally, it is acknowledged that there are limitations to the present study. Single respondents representing an entire organization (e.g., processing companies and input dealers) may have caused response bias. Nevertheless, this limitation was lessened due to the number of individual interviews with actors from different chain segments regarding the same phenomenon being analyzed.

Supplementary Materials: The following are available online at http:/ /www.mdpi.com/2071-1050/10/7/2215/s1.

Author Contributions: Conceptualization: L.O.d.S.; preparation of data collection procedure: L.O.d.S. and M.M.; data collection: L.O.d.S.; first Draft: L.O.d.S.; review and editing: M.D.P.F. and M.M.; and final version: L.O.d.S., M.D.P.F., and M.M.

Funding: This research was funded by the Brazilian Coordination for the Improvement of Higher Education Personnel, which awarded a doctorate scholarship to the first author (CAPES, BEX Number 9443/14-2), and by the German Federal Ministry of Education and Research (FKZ 031A281B), and the Brazilian Council for Scientific and Technological Development (CNPq-402022/2014-9), which were the funders of the SunflowerProtein project.

Acknowledgments: We are thankful to the founders of this research. Moreover, we are extremely grateful to all individuals and companies that provided the information necessary for the development of this article. Special thanks go to Marcos Gomes and Silvia Garcia for their support to the first author during the fieldwork. Furthermore, we gratefully acknowledge the contributions to English language review of the manuscript performed by Agnes Ewert. Finally, we thank the anonymous referees for their valuable comments on earlier versions of this article.

Conflicts of Interest: The authors declare no conflict of interest.

\section{References}

1. Aiking, H. Protein production: Planet, profit, plus people? Am. J. Clin. Nutr. 2014, 100, 483S-489S. [CrossRef] [PubMed]

2. Sabaté, J.; Soret, S. Sustainability of plant-based diets: Back to the future. Am. J. Clin. Nutr. 2014, 100, 476S-482S. [CrossRef] [PubMed]

3. Frost \& Sullivan. Trends and Opportunities in the European Protein Ingredients Market; Frost \& Sullivan: San Antonio, TX, USA, 2010.

4. Vainio, A.; Niva, M.; Jallinoja, P.; Latvala, T. From beef to beans: Eating motives and the replacement of animal proteins with plant proteins among Finnish consumers. Appetite 2016, 106, 92-100. [CrossRef] [PubMed]

5. González-Pérez, S.; Vereijken, J.M. Sunflower proteins: Overview of their physicochemical, structural and functional properties. J. Sci. Food Agric. 2007, 87, 2173-2191. [CrossRef] 
6. Wu, G.; Fanzo, J.; Miller, D.D.; Pingali, P.; Post, M.; Steiner, J.L.; Thalacker-Mercer, A.E. Production and supply of high-quality food protein for human consumption: Sustainability, challenges, and innovations. Ann. N. Y. Acad. Sci. 2014, 1321, 1-19. [CrossRef] [PubMed]

7. Zilberman, D.; Holland, T.G.; Trilnick, I. Agricultural GMOs-What we know and where scientists disagree. Sustainability 2018, 10, 1514. [CrossRef]

8. Pickardt, C.; Eisner, P.; Kammerer, D.R.; Carle, R. Pilot plant preparation of light-coloured protein isolates from de-oiled sunflower (Helianthus annuus L.) press cake by mild-acidic protein extraction and polyphenol adsorption. Food Hydrocoll. 2015, 44, 208-219. [CrossRef]

9. González-Pérez, S.; Merck, K.B.; Vereijken, J.M.; Van Koningsveld, G.A.; Gruppen, H.; Voragen, A.G.J. Isolation and characterization of undenatured chlorogenic acid free sunflower (Helianthus annuus) proteins. J. Agric. Food Chem. 2002, 50, 1713-1719. [CrossRef] [PubMed]

10. Weisz, G.M.; Kammerer, D.R.; Carle, R. Identification and quantification of phenolic compounds from sunflower (Helianthus annuus L.) kernels and shells by HPLC-DAD/ESI-MSn. Food Chem. 2009, 115, 758-765. [CrossRef]

11. Castro, C.; Leite, R.M.V.B.C. Main aspects of sunflower production in Brazil. OCL 2018, 25, 104. [CrossRef]

12. CONAB Séries Históricas de Área Plantada, Produtividade e Produção. Available online: http://www. conab.gov.br/conteudos.php?a=1252\&t=2 (accessed on 5 April 2018).

13. Dias, W.P.; Moraes, L.A.C.; de Carvalho, C.G.P.; de Oliveira, M.C.N.; Orsini, I.P.; de Leite, R.M.V.B.C. Resistance to Meloidogyne incognita, Meloidogyne javanica and Pratylenchus brachyurus in sunflower cultivars adapted to the tropical region of Brazil. Trop. Plant Pathol. 2016, 41, 325-330. [CrossRef]

14. Matsuura, M.I.S.F.; Dias, F.R.T.; Picoli, J.F.; Lucas, K.R.G.; de Castro, C.; Hirakuri, M.H. Life-cycle assessment of the soybean-sunflower production system in the Brazilian Cerrado. Int. J. Life Cycle Assess. 2017, 22, 492-501. [CrossRef]

15. Sousa, L.O.; Ferreira, M.D.P.; Vogt, L.; Mergenthaler, M. Contracts, social network and knowledge diffusion in Brazilian sunflower agri-food chains for potential supply of innovative food proteins. Rev. Econ. Agronegócio 2018, 16, 8-28.

16. Donovan, J.; Franzel, S.; Cunha, M.; Gyau, A.; Mithöfer, D. Guides for value chain development: A comparative review. J. Agribus. Dev. Emerg. Econ. 2015, 5, 2-23. [CrossRef]

17. Watanabe, K.; Zylbersztajn, D. Building Supply Systems from Scratch: The Case of the Castor Bean for Biodiesel Chain in Minas Gerais, Brazil. Int. J. Food Syst. Dyn. 2012, 3, 185-198. [CrossRef]

18. César, A. da S.; Batalha, M.O. Brazilian biodiesel: The case of the palm's social projects. Energy Policy 2013, 56, 165-174. [CrossRef]

19. Lie, H.; Rich, K.M.; Kurwijila, L.R.; Jervell, A.M. Improving smallholder livelihoods through local value chain development: A case study of goat milk yogurt in Tanzania Improving smallholder livelihoods through local value chain development: A case study of goat milk yogurt in Tanzania. Int. Food Agribus. Manag. Rev. 2012, 15, 55-86.

20. Birck, M.; Dalchiavon, F.C.; Stasiak, D.; Iocca, A.F.S.; Hiolanda, R.; Carvalho, C.G.P. Performance of sunflower cultivars at different seeding periods in central Brazil. Ciênc. Agrotecnol. 2017, 41, 42-51. [CrossRef]

21. Dalchiavon, F.C.; Malacarne, B.J.; Carvalho, C.G.P. De Características agronômicas de genótipos de girassol (Helianthus annuus L.) em segunda safra no Chapadão do Parecis-MT. Rev. Ciênc. Agrár. 2016, 39, 178-186. [CrossRef]

22. Dalchiavon, F.C.; Carvalho, C.G.P.; Amabile, R.F.; Godinho, V.d.P.C.; Ramos, N.P.; Anselmo, J.L. Características agronômicas e suas correlações em híbridos de girassol adaptados à segunda safra. Pesqui. Agropecu. Bras. 2016, 51, 1806-1812. [CrossRef]

23. Grunvald, A.K.; Carvalho, C.G.P.; Oliveira, A.C.B.; Andrade, C.A.d.B. Adaptability and stability of sunflower genotypes in Central Brazil. Pesq. Agropec. Bras. 2008, 43, 1483-1493. [CrossRef]

24. Grunvald, A.K.; Carvalho, C.G.P.; Oliveira, A.C.B.; Pires, J.L.F.; Carvalho, H.W.L.; Oliveira, I.R. Adaptability and stability of conventional and high oleic sunflower genotypes cultivated in southern Brazil. Amaz. J. Agric. Environ. Sci. 2014, 57, 217-223. [CrossRef] 
25. Grunvald, A.K.; Carvalho, C.G.P.; Leite, R.S.; Mandarino, J.M.G.; Andrade, C.A.d.B.; Scapim, C.A. Predicting the oil contents in sunflower genotype seeds using near-infrared reflectance (NIR) spectroscopy. Acta Sci. Agron. 2014, 36, 233-237. [CrossRef]

26. Grunvald, A.K.; De Carvalho, C.G.P.; Leite, R.S.; Mandarino, J.M.G.; De Bastos Andrade, C.A.; Amabile, R.F.; De Paulo Campos Godinho, V. Influence of temperature on the fatty acid composition of the oil from sunflower genotypes grown in tropical regions. JAOCS J. Am. Oil Chem. Soc. 2013, 90, 545-553. [CrossRef]

27. Dalchiavon, F.C.; Montanari, R.; Andreotti, M.; Dallacort, R.; Souza, M.F.P. Relationship between sunflower productivity and soil's chemical properties by geo-statistical techniques. Afr. J. Agric. Res. 2015, 10, 3525-3532. [CrossRef]

28. Venkataraman, S. The Distinctive domain of entrepreneurship research. Adv. Entrep. Firm Emerg. Growth 1997, 3, 119-138. [CrossRef]

29. Guterman, A.S. Definitons and Types of Entrepreneurship. Available online: http://link.springer.com/10. 1057/ ejdr.2011.61 (accessed on 2 April 2018).

30. Bygrave, W.D. The entrepreneurial process. In The Portable MBA in Entrepreneurship; Bygrave, W.D., Zacharakis, A., Eds.; John Wiley \& Sons: Hoboken, NJ, USA, 2010; pp. 1-26.

31. Ardichvili, A.; Cardozo, R.; Ray, S. A Theory of Entrepreneurial Opportunity Identification and Development. J. Bus. Ventur. 2003, 18, 105. [CrossRef]

32. Trienekens, J.H. Agricultural value chains in developing countries a framework for analysis. Int. Food Agribus. Manag. Rev. 2011, 14, 51-82.

33. Zhang, X.; Aramyan, L.H. A conceptual framework for supply chain governance: An application to agri-food chains in China. China Agric. Econ. Rev. 2009, 1, 136-154. [CrossRef]

34. Carayannis, E.G.; Samara, E.T.; Bakouros, Y.L. Innovation and Entrepreneurship: Theory, Policy and Practice; Springer: Cham, Switzerland, 2015.

35. Nassif, V.M.J.; Ghobril, A.N.; Silva, N.S. Understanding the entrepreneurial process: A dynamic approach. Braz. Adm. Rev. 2010, 7, 213-226. [CrossRef]

36. Yin, R.K. Case Study Research Design and Methods, 5th ed.; Sage Publications: Thousand Oaks, CA, USA, 2014.

37. Sterns, J.A.; Schweikhardt, D.B.; Peterson, H.C. Using case studies as an approach for conducting agribusiness research. Int. Food Agribus. Manag. Rev. 1998, 1, 311-327. [CrossRef]

38. Anastasiadis, F.; Poole, N. Emergent supply chains in the agrifood sector: Insights from a whole chain approach. Supply Chain Manag. 2015, 20, 353-368. [CrossRef]

39. Martìnez, J.M.C. Una Visión Dinámica Sobre El Empreendedurismo Colectivo. Rev. Neg. Blumenau 2004, 9, 91-105.

40. Granovetter, M. Economic Action and Social Structure: The Problem of Embeddedness. Am. J. Sociol. 1985, 91, 481-510. [CrossRef]

41. Uzzi, B. Social Structure and Competition in Interfirm Networks: The Paradox of Embeddedness. Adm. Sci. Q. 1997, 42, 35-67. [CrossRef]

42. Rosairo, H.S.R.; Potts, D.J. A study on entrepreneurial attitudes of upcountry vegetable farmers in Sri Lanka. J. Agribus. Dev. Emerg. Econ. 2016, 6, 39-58. [CrossRef]

43. Furlong, D. The Conceptualization of 'Trust' in Economic Thought; IDS Working Papers: Brighton, UK, 1996.

44. Galaskiewicz, J. Studying supply chains from a social network perspective. J. Supply Chain Manag. 2011, 47, 4-8. [CrossRef]

45. Hartmann, M.; Hoffmann, J.; Simons, J. Behavioural economics and the theory of social structure: Relevance for understanding inter-organizational relationships. In Agri-Food Chain Relationships; Fischer, C., Hartmann, M., Eds.; CABI: Oxfordshire, UK, 2010; pp. 61-73, ISBN 9781845936426.

46. Barney, J.A.; Hansen, M.H. Trustworthiness as a source of competitive advantage. Strateg. Manag. J. 1994, 15, 175-190. [CrossRef]

47. Keefer, P.; Knack, S. Social Capital, Social Norms and the New Institutional Economics. In Handbook of New Institutional Economics; Menard, C., Shirley, M.M., Eds.; Springer: Dordrecht, The Netherlands, 2005; pp. 701-726.

48. Knudson, W.; Wysocki, A.; Champagne, J.; Peterson, H.C. Entrepreneurship and innovation in the agri-food system. Am. J. Agric. Econ. 2004, 86, 1330-1336. [CrossRef]

49. Kahan, D. Entrepreneurship in Farming; FAO: Rome, Italy, 2012. 
50. Watanabe, K.; Bijman, J.; Slingerland, M. Institutional arrangements in the emerging biodiesel industry: Case studies from Minas Gerais-Brazil. Energy Policy 2012, 40, 381-389. [CrossRef]

51. Van Der Vorst, J.A.I.J.; Da Silva, C.A.; Trienekens, J.H. Agro-Industrial Supply Chain Management: Concepts and Applications; FAO: Rome, Italy, 2007; Volume 17, ISBN 9789251058312.

(c) 2018 by the authors. Licensee MDPI, Basel, Switzerland. This article is an open access article distributed under the terms and conditions of the Creative Commons Attribution (CC BY) license (http://creativecommons.org/licenses/by/4.0/). 